\title{
Cross Fire and Collaboration among Comparative Literature, Feminism, and the New Historicism
}

\author{
SARAH WEBSTER GOODWIN
}

Comparative literature as a discipline seems in recent years to have drifted into an uneasy peace. The heyday of comparatist controversywhen scholars from both sides of the Atlantic tossed the word "crisis" back and forth like a football of indeterminate shape-is long gone. Although in this country René Wellek has seemingly won out, and comparatists are supposed to be concerned with "criticism" rather than "history," with defining the literariness of literature and interpreting the canon in the light of weighty abstractions, in practice there is still a lot of source- and influence-hunting going on, a lot of thematology, the kind of literary history that is supposed to be of secondary interest. ${ }^{1}$ Much of it has been first-rate, but until the 1990s it remained somewhat overshadowed by giants such as Paul de Man, whose reputations seemed - to switch metaphors-to rise and hover over the discipline of comparative literature, taking on a being and a community of their own. (I do not intend to make them sound quite so much like an angelic host, but the image insistently presents itself.) De Man and his peers belonged to literary criticism and theory more generally, not primarily to comparatists.

But even such absent comparatist giants as they seem to be missing in the 1990s. Feminist literary theory and criticism has an international cast, and feminists are exerting themselves with real intensity to build common models out of disparate cultural materials. Much of the most interesting recent feminist work attempts to mediate between the conflicting models and assumptions that have brought that field to a crisis of its own. ${ }^{2}$ But feminism has remained surprisingly absent from the disciplinary corridors of comparative literature, and the issues and in-

${ }^{1}$ A point made by Henry H. H. Remak, "Comparative Literature: Its Definition and Function," in Comparative Literature: Method and Perspective, ed. Newton P. Stallknecht and Horst Frenz (Carbondale: Southern Illinois University Press, 1971), 1-10, 330n.

${ }^{2}$ See, for example, Marianne Hirsch and Evelyn Fox Keller, eds., Conflicts in Feminism (New York: Routledge, 1990). 
tensities that drive feminist debate seem larger, more pressing, than the problem of defining a distinctly comparatist methodology which so exercised comparatists a generation or two ago. Similarly, the historicist criticism that has come increasingly to occupy center stage in critical discourse goes after the big fish: nothing less is at stake than the relations of culture and politics to literary criticism, both what we write and what we teach. Although the "border disputes" that some of the new historicists have ensnared themselves in may seem petty at times, they also clearly grow out of deeply held beliefs about why literary criticism matters and how it might help bring about a better world. Both feminist and historicist critics define their work as distinct from the aesthetics of formalism. In the context of their politicized rhetoric, matters such as a definition or even a defense of comparative literature seem circumscribed, academic - and as dull as a football game in July. The real skirmishes are elsewhere.

If comparative literature itself has come to seem dull, it is not because dullness inheres in its subject matter. On the contrary. Nothing could be more pertinent to the current climate of cultural criticism than the problems of defining cultures and their exchanges which constitute the natural domain of comparatist work. ${ }^{3}$ Furthermore, comparative literature offers the rare example of a feminist critic and scholar-Germaine de Staël-as one of its earliest and most influential theorists. De Staël's contribution makes it clear that feminist, historicist theory lies at the very heart of comparative literature; the work of comparing literary cultures engages that of comparing and constructing genders. Feminism and historicism should come naturally to comparative literature.

Both feminist and historicist thought helped constitute the speculative works that established comparative literature. Both, I would argue, are inherently comparatist in nature, although both have subsided in importance in recent years. There is one major difference between the two, however, and the difference in this case is all. After Germaine de Staël, feminist speculation apparently disappeared entirely from comparatists' methodological debates. In contrast, history in its various guises remained a kind of obsession for comparatists, and retreated in importance only late and briefly, under the pressure of late New Criticism and the work of the Yale school. ${ }^{4}$ For this reason, the return of

${ }^{3}$ I am grateful for the insights of Michel-André Bossy in private conversation and in his unpublished paper "Comparative Literature in the 1990s: Notes toward an Axiology." They have contributed much to this argument.

${ }^{4}$ In turn, Marjorie Levinson calls the new historicism “a direct assault upon Yale's 
history to the nexus of comparative literature may occur more effortlessly than that of feminist cultural theory, which has its long absence to account for and overcome.

The reasons for both these disciplinary tendencies within comparative literature-an ongoing interest in history, and a resistance to the feminist issues raised by one of its seminal theorists-are not hard to adduce. Because of the historical association between comparative literature and nationalism, because comparatists must incorporate consideration of cultural self-definition and boundaries into their work, the discipline has a long-standing and complex relation with the theorizing of politics and history. ${ }^{5}$ And because comparative literature, even more than national literatures, traditionally defines its concerns around an elite and exclusively male canon-its sources, influence, branches, and subcanons-it has resisted with particular force the inroads of feminist criticism.

And yet despite these historical differences it seems clear that both feminists and historicists have much to gain from each other. As has become evident in the work of the new historicists, feminist thought has brought significant influence to bear on the categories of historical thought currently in use. At the same time, the larger methodological discussions taking place about the relations between history and literary theory have given feminists a position for debate more potentially central than any other they have occupied in recent history.

The basis for an alliance, however stormy, between historicists and many feminists lies in the conceptions of history and of culture which they are likely to share. For both, "historicizing" the text means reading it in a context to which it is integrally related. History is not a "backdrop," not something of inferior interest from which the text emerges in order to transcend it. ${ }^{6}$ Nor is history construed as a unitary worldview or zeitgeist, nor even as explanatory narratives of cause and effect. Rather, history is a problem: fact, causality, cultural unity come into question as the possible creations of hegemonic groups. Text and context are alike discursive, and contribute together to cultural selfconstruction. Literary texts are not privileged over other kinds of texts

\footnotetext{
present-mindedness"; see her essay "The New Historicism: Back to the Future," in Rethinking Historicism: Critical Readings in Romantic History, ed. Marjorie Levinson et al. (Oxford: Basil Blackwell 1989), 18-63.

${ }^{5}$ Comparatists who speculate about the nature of their discipline discuss its political dimension, whether or not they consciously foreground it. See, for example, François Jost, Introduction to Comparative Literature (Indianapolis: Bobbs-Merrill, 1974), vii.

${ }^{6}$ This sentence paraphrases Carolyn Porter's thoughtful feminist critique of the new historicism, "Are We Being Historical Yet?" South Atlantic Quarterly 87 (1988): 770.
} 
except insofar as their representations may be more multifaceted, complex, or self-contradictory. Historicists and feminists share an interest in the ways texts trace the creation, subversion, containment, and conception of power. They also share, in theory, a sense of being themselves historically positioned as readers and writers. ${ }^{7}$

A number of feminists have criticized the new historicism more than they have praised it, but they have not ignored their affinities with its tenets. Judith Lowder Newton has conveniently and sympathetically collated a number of historicists' self-definitions:

Those engaged in "new historicism," we are told, generally assume that there is no transhistorical or universal human essence and that human subjectivity is constructed by cultural codes which position and limit all of us in various and divided ways. They assume there is no "objectivity," that we experience the "world" in language, and that all our representations of the world, our readings of texts and of the past, are informed by our own historical position, by the values and politics that are rooted in them. They assume, finally, that representation "makes things happen" by "shaping human consciousness" and that as forces acting in history various forms of representation ought to be read in relation to each other and in relation to non-discursive "texts" like "events." .. . There is the notion that "history" is best told as a story of power relations and struggle, a story that is contradictory, heterogeneous, fragmented. There is the (more debated) notion that hegemonic power is part but not all of the story, that "history" is a tale of many voices and forms of power, of power exercised by the weak and the marginal as well as by the dominant and strong. ${ }^{8}$

I quote Newton at some length because this is the best brief definition of the new historicism I know of, although she goes on to argue that there is nothing new or original about any of this, that it is just "history as usual," being practiced by a group of male scholars who fail to ac-

${ }^{7}$ This paragraph makes a series of broad generalizations, each of which could entail lengthy debate, qualification, and documentation. Although it offers a basic, probably uncontroversial idea of the now familiar new historicist givens, it assumes a commonality among feminists that is certainly misleading, given both the virulent attacks by some feminists on new historicism and the methodological conflicts among feminists themselves. Still, even as pointed an attack as Carol Thomas Neely's on the "cult-historicists," whose effect she says "has been to oppress women, repress sexuality, and subordinate gender issues," acknowledges the "liberating and regenerative effect" of an approach that also can be seen to provide support for feminist claims that all literature is political; see her essay "Constructing the Subject: Feminist Practice and the New Renaissance Discourses," English Literary Renaissance 18 (1988): 7. For more distinctions among historicisms and the critiques of them, see Jonathan Dollimore, "Shakespeare, Cultural Materialism, Feminism, and Marxist Humanism," New Literary History 21 (1990): 471-93.

8Judith Lowder Newton, "History as Usual? Feminism and the 'New Historicism,'" in The New Historicism, ed. H. Aram Veeser (New York: Routledge, 1989), 152. 
knowledge their feminist and other predecessors. Nevertheless, we are a long way from the comparatist Paul van Tieghem's assertion in 1931 that "Comparative Literature studies the actions and influences exerted by individuals." ${ }^{\prime 9}$ No such positivistic concepts as actions and individuals inform the new historicism. None of the familiar historical categories is simply a given: fact, causality, nation, event, objectivity, agency-or meaning.

The result is a kind of criticism pointedly banned by the comparatist Horst Rüdiger as late as the 1966 inaugural issue of Arcadia: Zeitschrift für Vergleichende Literaturwissenschaft: Rüdiger outlawed "the discussion of all historical parallels based solely on speculation." ${ }^{10}$ For the new historicism, "speculation" is all we have. Rüdiger believes that there are bases for drawing historical parallels to establish homologies between texts that possess factuality or truth-value, but the new historicist would argue that those "bases" for homologies are themselves only texts, subject to interpretation. ${ }^{11}$ As Newton points out, the new historicist argument echoes poststructuralist epistemologies that cannot shock anyone, however much they may dismay some who seek a retreat from the alleged hegemony of theory in the academy. The apparent inevitability of the new historicist inquiry in comparative literature follows from the critical developments of the 1970 s and 1980s, in which the remnants of positivism have been swept away. It also draws strength from the revelations about de Man's personal history, which have elevated in importance our own historical context as critics. The new historicism thus seems logically unavoidable, even if already ephemeral as a distinct school, precisely because its givens are so familiar.

It is clear that the idea of history sketched here differs significantly from the ways comparatists have understood history in the past. I would also argue that such a renovated view of history, actively integrated into comparatist work, stands to open the borders for feminism in comparative literature-or, to sidestep the chivalric gesture, to put feminists in a better methodological position to storm the checkpoints for themselves. A feminist, historicist criticism is both desirable and possible in comparative literature, despite practical difficulties; it could

${ }^{9}$ Quoted in Ulrich Weisstein, Comparative Literature and Literary Theory: Survey and Introduction (Bloomington: Indiana University Press, 1973), 4.

${ }^{10}$ Horst Rüdiger, "Zur Einführung," Arcadia: Zeitschrift für Vergleichende Literaturwissenschaft 1 (1966): 3 .

${ }^{11}$ This is a problem that has received some attention, since much new historicist work proceeds by drawing parallels between disparate texts and then basing a larger cultural claim on those parallels-which themselves at times seem tenuous or fanciful. See Carolyn Porter's critique of Stephen Greenblatt, in Porter, "Are We Being Historical Yet?" $762-63$. 
indeed reenergize a languishing field. I intend this argument not as a blueprint for silencing controversy, but as one for reviving it. The cross fire and the collaboration we are seeing along the old disciplinary borders are leading us to redraw the maps. Comparative literature can no longer stand by as neutral territory.

Comparative literature's early associations with history as a discipline would seem to have been crucial, if relatively contested. The earliest comparatists thought in terms of historical context. I have already mentioned the importance of Germaine de Staël, the "pioneer comparatist" whose De l'Allemagne (1813) is still famous, but who also wrote an early work of what might be called historicist-and also feministcomparative literature, De la littérature considérée dans ses rapports avec les institutions sociales (1800). ${ }^{12}$ Although Staël's methodological influence has not yet fully been traced, after her the work of early comparatists remained very closely aligned with that of historians. ${ }^{13}$ According to Ulrich Weisstein, the first major conference on comparative literature took place in Paris in 1900 within the context of an international congress of historians, and in both France and Germany comparatists long saw their work as "a branch of literary history rather than literary criticism or theory." 14 There is no need to repeat here the convoluted history of comparatists' attempts to define their discipline; it can be read in any handbook..$^{15}$ It is perhaps simply worth noting that the discipline acquired its earliest institutional coherence in France, where Taine and the practice of a positivist history had a long-standing influence on comparatist thought. By later in the century there was also considerable

${ }^{12}$ The phrase "pioneer comparatist" is from A. Owen Aldridge, ed., Comparative Literature: Matter and Method (Urbana: University of Illinois Press, 1969), 2. According to Paul van Tieghem, the French comparatist who championed historicist criticism earlier in this century, her work was foundational; see his introduction to Mme. de Staël, De la littérature considérée dans ses rapports avec les institutions sociales, ed. Paul van Tieghem (Geneva: Droz, 1959), 1:vii-lxvi. Like most of the male commentators on her groundbreaking essay, he stresses her intuitiveness; unlike them, he also notes the importance of her feminism to her study (xiii, xxvii).

${ }^{13}$ There lies a story to tell in the erasure of Staël's presence. Consistently, histories of the discipline mention her and then drop the subject. Ulrich Weisstein, Comparative Literature, calls her book De l'Allemagne a "palimpsest" of comparative literature, an overt and unembarrassed metaphor of erasure. More typical is the overture of praise followed by dismissal offered by Hugo Dyserinck: he calls her work decisively influential, then dismisses it for being limited in its point of view; see his Komparatistik: Eine Einführung (Bonn: Bouvier, 1977).

${ }^{14}$ Weisstein, Comparative Literature, 174-75, 185.

${ }^{15}$ The most lucid example I know of in English is Weisstein's appendix (ibid., 167-252). See also P. Brunel et al., Qu'est-ce que la littérature comparée? (Paris: Armand Colin, 1983), 15-30; and Dyserinck, Komparatistik, 17-86. Also useful is Remak, "Comparative Literature," which includes an annotated bibliography. 
influence from the German hermeneutic tradition, with its historicizing methods. Despite the more ahistorical influence of Goethe and Schlegel in their concepts of Weltliteratur and Universalpoesie, professional comparatists long had to define their methodology with reference to history.

One way of linking history and literature was to hitch chronologies of literary texts on to the models of historical periodization that history scholars were bent on defining, largely based on monarchs or ruling regimes. Traditional twentieth-century narratives of the discipline's own history point out that the early stages of comparative literature in the nineteenth century are very closely linked to the development of literary history as an idea, but imply that those stages are far behind us, despite the fact that periodization remains the primary organizing feature of both our pedagogy and our professional practice. René Wellek and Austin Warren's Theory of Literature, adopting a formalist position, dismisses any idea of comparative literature "conceived ... on externals," and notes that "the decline of this type of "comparative literature' in recent decades reflects the general turning away from stress on mere 'facts,' on sources and influences." History, even "literary" history, if construed as "mere facts," seemingly would only distract from the more strictly aesthetic qualities of the texts. ${ }^{16}$ We recognize here the terms of the famous crisis in comparative literature of the 1950 S and 1960s, in which the "American school" rejected the alleged French obsession with rapports de fait, "factual connections," and argued for the importance of "criticism" over "history."17

But that one crisis was merely part of the ongoing discussion in comparatist self-definitions about the function of history in comparative literature. Under the influence of Wellek and Warren, for a time history seemed decidedly extrinsic to literary matters. Attempts to define an

\footnotetext{
${ }^{16}$ René Wellek and Austin Warren, Theory of Literature, 3d ed. (New York: Harcourt Brace, 1956), 48. For distinctions among kinds of literary history, see 252-69. As Wellek and Warren point out, the phrase covers a wide range: "Most histories of literature... are either social histories, or histories of thought as illustrated in literature, or impressions and judgements on specific works arranged in more or less chronological order" (252). They propose instead an idea of literary history that is based on intrinsically literary qualities, which I discuss later in this essay.

${ }^{17}$ According to the French position in that debate, comparatist literary histories were to be closely modeled on the nineteenth-century elaboration of a positivist history, relying for truth-value on the idea of documentable fact, and for argument on the idea of development and progress. René Wellek and many others called these concepts into question, as do the new historicists, in somewhat different terms. For a well-reasoned account of the crisis, see Dyserinck, Komparatistik, 49-64. See also, principally, René Wellek, "The Crisis of Comparative Literature" (1959), in his Concepts of Criticism (New Haven: Yale University Press, 1963), 282-95, subsequently cited in the text; and René Étiemble, Comparaison n'est pas raison: la crise de la littérature comparée (Paris: Gallimard, 1963).
} 
intrinsically literary history have grown out of formalist criticism, and have involved histories of genres, morphologies, thematic criticism, and the like. Wellek and Warren place this kind of literary history in the section of their book called "The Intrinsic Study of Literature." And yet there has also been a long-standing tradition of comparatist literary history that approaches intellectual and even social history, especially in France and Germany, where the generic boundaries between literature and philosophy have always been more fluidly drawn than in the English tradition. The distinction between extrinsic and intrinsic matters, which now is undergoing redefinition in this country, has never been universally accepted. ${ }^{18}$

If we return to Wellek's 1959 argument for a criticism based on intrinsic matters, we find a position that seems dated, but that also intelligently lays the groundwork for breaking down the very distinctions on which it rests, preparing the way for a new and different historicism in comparatist studies:

Literary scholarship today... must be distinguished from the study of the history of ideas, or religious and political concepts and sentiments which are often suggested as alternatives to literary studies. Many eminent men in literary scholarship and particularly in comparative literature are not really interested in literature at all but in the history of public opinion, the reports of travelers, the ideas about national character-in short, in general cultural history. The concept of literary study is broadened by them so radically that it becomes identical with the whole history of humanity. But literary scholarship will not make any progress, methodologically, unless it determines to study literature as a subject distinct from other activities and products of man. Hence we must face the problem of "literariness," the central issue of aesthetics, the nature of art and literature.

... The work of art, I have argued, can be conceived as a stratified structure of signs and meanings which is totally distinct from the mental processes of the author at the time of composition and hence of the influences which may have formed his mind. There is what has been rightly called an "ontological gap" between ... life and society on the one hand and the aesthetic object. I have called the study of the work of art "intrinsic" and that of its relations to the mind of the author, to society, etc., "extrinsic." (293-94)

${ }^{18}$ Basil Munteano took up precisely this issue in "Situation de la littérature comparée: sa portée humaine et sa légitimite," in Proceedings of the Second Congress of the International Comparative Literature Association, University of North Carolina Studies in Comparative Literature, 23-24 (1959), 1:124-42. Munteano rejects the distinction between "extrinsic" and "intrinsic" criticism, and argues for a dialectical method. 
It would seem hard to draw a more rigorous division between literature and history. And yet, curiously, Wellek goes on to qualify himself in a vein that has been largely ignored: "Still, this distinction cannot mean that genetic relations should be ignored or even despised or that instrinsic study is merely formalism or irrelevant aestheticism. Precisely the carefully worked out concept of a stratified structure of signs and meanings attempts to overcome the old dichotomy of content and form. ... Nothing would be further from my mind than to ... erect a barrier between history and formal study" (294). Indeed, it is the vocabulary of "structure," of "signs and meanings," that breaks down the very barrier he has begun to erect. If the work of art consists of such structures, so too might the author's mental processes, the influences on them, the society in which those influences have arisen, and the texts in which we may trace those structures. Inadvertently, Wellek points the way for comparative literature to take as its proper domain precisely a consideration of the interrelationships among such larger structures, specifically in the international context. It is no accident that his essay argues repeatedly for a comparatist criticism that will break down international barriers. He closes it by asserting, heatedly, that "once we conceive of literature not as an argument in the warfare of cultural prestige, or as a commodity of foreign trade or even as an indicator of national psychology ... national vanities will disappear" (295). Wellek's vocabulary here sets up a system of interrelated structures. Psychology-collective and individual-interlocks with metaphors of warfare and trade in a complex system which encompasses literary texts and criticism. The scholar cannot step outside that system, but can evidence greater or lesser awareness of it. Wellek introduces here the very vocabulary of commodity, circulation, and trade which characterizes new historicist analysis. And he does so pointedly in the context of international exchange.

It is that concern with nationalism and with boundaries that makes history a natural subject for comparatists. The relation between national literatures and cultural boundaries lies at the heart of the comparatist enterprise and inevitably raises historical and cultural questions. It is by now no secret that the development of literary studies has followed closely the growth of nationalist sentiment in Western cultures. ${ }^{19}$ But this does not mean that the borders of modern nations coincide tidily with those of their cultures, and there are countless borderline areas. It

\footnotetext{
${ }^{19}$ See, for example, Wellek and Warren, Theory of Literature, 51; Albert Guérard, "Comparative Literature?" Yearbook of Comparative and General Literature 7 (1958): 1-6; Gerald Graff, Professing Literature (Chicago: University of Chicago Press, 1987).
} 
may seem like splitting hairs to question, as Ulrich Weisstein does, whether Heinrich Mann should be considered a German, French, Czech, or American author for the purpose of genuine comparatist work, depending on the respective weight one chooses to lend language, milieu, and citizenship. ${ }^{20}$ It is an issue long familiar to English departments in this country, where T. S. Eliot is variously taught in both British and American literature surveys. Does it matter? I would argue that it matters when the decision to cast an author this way or that rests on the political and historical dimensions of his or her affiliations-and that the assumptions behind the choice must themselves be made explicit. In the same discussion Weisstein asks whether it is "comparatist" to compare an East German author with a West German, a question that might in the light of the reorganization of Germany be supplanted by another one: whether a German-language author living in Silesia should be regarded as a Slav or a German. To make the choice is to take sides in a political debate about how "Germany" is to be defined.

What is at stake here is the historical assumption underlying comparative literature as a discipline: that the comparatist's work juxtaposes texts from discrete national literatures. Earlier in his 1959 essay Wellek identifies what he calls a "paradox in the psychological and social motivation of "comparative literature'" as practiced in this century: a tension between the desire to overcome nationalism and a "strange system of cultural bookkeeping," in which the goal is to accumulate points for one's own nation (287-89). The paradox Wellek locates in comparative literature still stands: it is not just the notorious western Europe-focused ethnocentricity of comparatists that underscores a dominant cultural self-conception, but also their very definitions of what they compare. Like national literature departments, for example, comparatist faculty have traditionally excluded from consideration French, German, or British literatures of non-Continental cultures. And as in those departments, opening the borders to include such literatures is necessarily a political step entailing a historicizing of the curriculum.

If, as I have been suggesting, comparative literature as a discipline inclines toward historical problems, how would the new historicism affect it? One characteristic of the new historicist work is the nature of the contemporary texts it chooses as the context for its readings: political debates, economics, domestic manuals, popular literature, advertising, legal pamphlets-texts that challenge rather than support the

\footnotetext{
${ }^{20}$ Weisstein, Comparative Literature, 11.
} 
hallowed status of the literary. New historicists' concerns are with class, gender, and the shifting representations of power, that elusive Foucauldian force that is exercised only in social contexts and that the literary text may both represent and contest, subvert and contain.

Perhaps the most significant difference between earlier work in what we might call "old" historicist criticism and the new historicism is that identified in an unsympathetic essay by Martin Mueller, published in Profession 89. Mueller contrasts what he calls a "hermeneutics of charity," in which the reader is generous to the text, with the notorious "hermeneutics of suspicion" practiced by the new historicists:

[The New Criticism said:] Read a text or author until you have found the meaning that combines the highest degree of thematic complexity with the highest degree of structural coherence. Now we have an opposite version, which says: Read a text or an author until you have found the meaning that combines the highest degree of ignorance with the highest degree of complicity. ${ }^{21}$

Although this is a caricature, it is not entirely inaccurate: for the new historicist the text is far from sacred. On the contrary, one of the central concerns of scholars such as Stephen Greenblatt, Catherine Gallagher, Laura Brown, and Jerome McGann has been to show the complicity between the literary text and constraining ideologies. Comparative literature came of age as a discipline during the era of charity, when criticism's calling was to celebrate "world" masterpieces. To shift to suspicion means an even more violent rupture for comparatists than for national literature scholars.

This may lead us to some understanding of why the new historicist work has taken place in the context of national literatures, especially English and American, rather than in comparative literature. There are also practical considerations; it is difficult enough to research contemporary documents in one language and culture without multiplying the logistical problems by two or three. Comparative literature is much easier to practice as a formalist criticism: it requires just the reader and the books. In contrast to scholars of English literature, who can often obtain primary sources in this country, comparatists require greater resources and mobility to do historical research. This is not merely a practical issue but one related to a larger problem for comparatists his-

\footnotetext{
${ }^{21}$ Martin Mueller, "Yellow Stripes and Dead Armadillos," Profession 89 (1989): 29. Although Mueller does not say so, the phrase "hermeneutics of suspicion" is not his own, but has been used repeatedly and variously attributed by others. It appears to have originated with Paul Ricoeur.
} 
torically: it is very difficult to be fully conversant with a text not just in its literary contexts but also in its cultural, political, social, and economical contexts. The difficulty multiplies with each additional language and culture one approaches. Whatever the difficulties for the comparatist, however, historicist criticism has much to recommend it. It moves away from formalist concerns that enforce a narrow conception of the comparatist canon, and that isolate literature from other aspects of culture. The practice of a historicist criticism is likely also to be coupled with a return to the vexed issue of national and cultural boundaries, this time with fresh critical perspectives. ${ }^{22}$

Because of such theoretically informed and ground-breaking comparatists as Wellek and Warren, de Man, and others, and because American comparatists have been well placed to follow developments in critical theory from the Continent, the discipline has generally not stagnated in this century but has more often been in the avant-garde. For better or worse, the new historicism is the new avant-garde, especially if we consider it more broadly in its affinities with feminism and cultural studies. Claims have been made repeatedly that new historicism is a peculiarly American phenomenon, despite influences from Foucault, the Frankfurt school, and especially British cultural materialists such as Raymond Williams. ${ }^{23}$ But it is perfectly possible to do new historicist work without being steeped in Foucault and Adorno: it is striking how little theory appears in Representations, and Stephen Greenblatt has admitted that in his case the practice comes before the theory. ${ }^{24}$ The acknowledged pioneers of the new historicism have come out of English studies, primarily in the Renaissance and Romanticism. Comparatists are having to run to catch up. Should we?

\footnotetext{
${ }^{22}$ No doubt British and German comparatists have already undertaken some of this work, under the influence, respectively, of British cultural materialism and the Frankfurt school. For a German view of comparative literature as a discipline that is integrally historical, despite its inflection of relatively conventional categories of comparatist research, see the essays in Manfred Schmeling, ed., Vergleichende Literaturwissenschaft: Theorie und Praxis (Wiesbaden: Athenaion, 1981). The volume makes no mention of feminism or gender criticism.

${ }^{23}$ There is a growing and at times impassioned literature on the differences among new historicisms. See, for example, Dollimore, "Shakespeare"; Lynda Boose, "The Family in Shakespeare Studies; or-Studies in the Family of Shakespeareans; or-The Politics of Politics," Renaissance Quarterly 40 (1987): 707-42; Joel Fineman, "The History of the Anecdote: Fiction and Fiction," in Veeser, New Historicism, 49-76, esp. 65; and Marlon B. Ross, "Contingent Predilections: The Newest Historicisms and the Question of Method," Centennial Review 34 (1990): 485-539.

${ }^{24}$ Stephen Greenblatt, "Towards a Poetics of Culture," in Veeser, New Historicism, 114. For a discussion of the paucity of theory in the new historicism, see Ross, "Contingent Predilections."
} 
It seems to be precisely this sense of the new historicism as the avantgarde-or the latest trend, to put it less generously-that makes for uneasy relations between historicists and feminists. In fact, I have been writing about the new historicists as though they were a phenomenon almost entirely distinct from feminism. This is clearly not the case. Judith Lowder Newton argues, as we have seen, that feminists have anticipated every important aspect of new historicist work. Newton asserts this as though the historicists had not paid their debts, even though she cites the talk in which Catherine Gallagher credited her own feminism with shaping her critical development and, seemingly, that of other new historicists. ${ }^{25}$

And yet it is true that new historicists, most often men, frequently write as though they had been influenced by feminist thought without, however, citing specific sources. To mention just two examples: Stephen Greenblatt, in a 1990 entry in Critical Terms for Literary Study, defines culture as "a particular network of negotiations for the exchange of material goods, ideas, and-through institutions like enslavement, adoption, or marriage-people." His condensed bibliography cites Bakhtin, Benjamin, Elias, Geertz, and Raymond Williams-all men, with no mention of Irigaray, or of others who have written with so much illumination about the symbolic exchange of women. Similarly, in an essay published in a 1989 volume, Joel Fineman claims that the new historicism seems to be peculiarly American in tenor, but he fails to identify American feminism as a contributing factor. He makes no mention that it is American feminist theory that has negotiated the straits between textuality and materialism during the last decade or two, focusing on the construction of gender as its model. In the same volume, Louis Montrose is more generous, citing a long series of ground-breaking feminist works in Renaissance studies, and granting feminist theory real prominence: "In the United States, it is Feminism and the Women's Movement which in recent years have provided the most powerful infusions of intellectual and social energy into the practices of cultural critique. ${ }^{\prime 26}$ It is an exceptional argument for a male new historicist.

\footnotetext{
${ }^{25}$ Gallagher's talk, cited in Newton, "History as Usual?" appears as "Marxism and the New Historicism," in Veeser, New Historicism, 39-48. Gallagher narrates the development of her critical position in a curious mix of the third-person and first-person plural, though it is not fully clear whom she means to include by her phrase "this generation of critics" (40).

${ }^{26}$ Stephen Greenblatt, "Culture," in Critical Terms for Literary Study, ed. Frank Lentricchia and Thomas McLaughlin (Chicago: University of Chicago Press, 1990), 229; Fineman, "History of the Anecdote," 65n; Louis A. Montrose, "Professing the Renaissance: The Poetics and Politics of Culture," in Veeser, New Historicism, 26. For various persuasive
} 
These and the other essays in The New Historicism may well exemplify the relations generally between feminist and new historicists, reflecting the visibility and vigor of the feminist critiques. In the volume there is a range of positions, with Montrose representing the most deference to feminist theory, and Catherine Gallagher, among the women, representing the least tension between new historicism and feminism. Other essays by women convey downright hostility, the most unequivocal by Jane Marcus, who argues that a "'feminist' New Historicism is ... even more limited and dangerous than other varieties of this technique." 27 Both Marcus and Newton assert that new historicist work is less new than it claims to be because it fails to take into full consideration the feminist methodology that has been worked out over recent decades. They thus repeat and elaborate critiques of new historicist work that had been made previously by Lynda Boose, Carol Thomas Neely, Carolyn Porter, and Marguerite Waller.

Newton's key argument in that volume, in her critique of Catherine Gallagher's Industrial Reformation of English Fiction, harks back to an old quarrel between feminists and Marxists. Feminists have held that classcentered theories do not suffice to interpret the experience of women, whose class is defined not by their work but through the symbolic exchanges taking place in marriage. As a result, Newton argues, studies that place class rather than gender at the center of their critical readings just do "history as usual," without the genuine change in perspective that comes when gender is placed at the center of the critical method. ${ }^{28}$ Thus, she argues, because the new historicism still relies on "malecentered" categories and events, it generally fails to be new, even when it incorporates some critiques of gender ideologies.

The problem is very similar to the one identified and summarized earlier by Catharine A. MacKinnon in her well-known essay in Signs, "Feminism, Marxism, Method, and the State: An Agenda for Theory." For MacKinnon, there are seemingly irreconcilable differences between Marxism and feminism, and attempts to reconcile them (surely one of

feminist critiques of the way new historicists marginalize women, see Boose, "Family in Shakespeare Studies"; Neely, "Constructing the Subject"; Porter, "Are We Being Historical Yet?"; and Marguerite Waller, "Academic Tootsie: The Denial of Difference and the Difference It Makes," Diacritics 17 (1987): 2-20. For the extreme opposite tendency, however, see Richard Levin's attack on new historicism, "Unthinkable Thoughts in the New Historicizing of English Renaissance Drama," New Literary History 21 (1990): 433-47. Levin mentions in his first sentence that he is critiquing the new historicists, the cultural materialists, and "a number of feminists associated with them" (as escorts?), although he never names a woman, even when he discusses gender issues.

${ }^{27} J a n e$ Marcus, "The Asylums of Antaeus: Women, War, and Madness-Is There a Feminist Fetishism?" in Veeser, New Historicism, 138.

${ }^{28}$ Newton, "History as Usual?" 159; subsequent references are cited in the text. 
the projects of some new historicist work) inevitably founder. On the one hand, MacKinnon says, Marxists charge feminists with being "bourgeois in theory and practice," with ignoring class differences "in the interest of the ruling class." In return, feminists charge that Marxism is male-centered: "It moves within the world-view and in the interest of men." The problem for MacKinnon, as for Newton, is that class is ineluctably a male-focused category: "Women derive their class position...from their associations with men" (7). The position that MacKinnon occupies at the end of her essay is very similar to that of Newton. Their vision is hierarchical, and feminism is at the top. As MacKinnon puts it:

Feminism stands in relation to marxism as marxism does to classical political economy: its final conclusion and ultimate critique. Compared with marxism, the place of thought and things in method and reality are reversed in a seizure of power that penetrates subject with object and theory with practice. In a dual motion, feminism turns marxism inside out and on its head. ${ }^{29}$

The gesture is triumphant, but is it persuasive?

I think not, on at least two counts. MacKinnon here explicitly aligns feminism with "things" and with "reality," and the triumphant tone of her prose derives in part from her happily physical metaphor, which dares to leave abstraction behind and fight with its hands. But at what cost? The assertion that feminism is more "real" than Marxism is not one that can be defended if proposed outright. Indeed, Marxism itself in many guises tries to lay claim to truth-value via the "real," by locating cultural within material production. As Elaine Scarry has argued at some length, the material body has an ultimate authority in discourse; MacKinnon is trying an old rhetorical tactic in appropriating some of that authority for feminism. The price is high: it returns us to the familiar, meretricious alignment of femininity with the body and of masculinity with the mind. Just as feminist theorists have generally moved away from the "authority of experience," the argument ad feminam, the feminist claim to truth-value cannot lie in the woman's guts.

But this is not the heart of Newton's argument, and she requires a separate and more thoughtful answer. ${ }^{30}$ Newton proposes that any

${ }^{29}$ Catharine A. MacKinnon, "Feminism, Marxism, Method, and the State: An Agenda for Theory," reprinted in Feminist Theory: A Critique of Ideology, ed. Nannerl Keohane et al. (Chicago: University of Chicago Press, 1981), 3, 4, 30.

${ }^{30}$ Newton does conclude her essay with a cautious allusion to the authority of the "real" and to feminism's seemingly privileged relation to it (166). See also Carol Thomas 
valid historicist criticism must use gender as one of its central categories, if not its most central one. The phrasing is mine, not hers, and she carefully avoids a vocabulary of validity, of success and failure, and instead addresses what might or might not be new in the new historicism, aligning novelty here with value. (The adjective that does come up, rather than valid, is adequate - clearly more cautious and positional [166].) The value of novelty for her, of course, is not its routine commodified value but its potential for bringing about change, the one constant and serious challenge Newton's essay makes. Her gravest criticism of the new historicism is that not only does it not contribute to any program of social change, but it undermines the conditions in which change might be brought about. ${ }^{31}$

The key to Newton's argument, and also its crux, is to be found here. She evaluates the three historicist critical texts she considers according to one major criterion: their value for social change. This value emerges from the "political considerations" Newton identifies with an activist feminism that sees "human agency as possible," that makes "gender relations ... central to history," and that takes material conditions into account (160).

Although I very much sympathize with Newton's sense of an urgent need for social change, I would argue that she presents here what amounts to a narrow prescription for critical practice. Working backwards from her final point, I suggest first of all that effective feminist criticism need not necessarily take "material conditions" - narrowly defined-into account, that the study of a wide and diverse range of texts and materials is essential to working out the full implications of feminism for our history and our culture. Second, it is equally confining to insist that gender relations be the central concern of every study of which they might be a part. This is a large subject by itself, and might best be approached in response to Newton through a defense of Catherine Gallagher's book, in which the analysis of gender issues is effectively situated in the context of other contemporary issues and debates. Newton complains that in Gallagher's book "events or social developments are largely male, and/or are those which have been traditionally seen, and are seen here, in terms of men" (159), as though such

Neely's objection to "the new theoretical discourses" generally: "They go further ... than most American liberal feminists have done in denying subjectivity, interiority, identity which is continuous across time and not the construct of ideology. Most American feminists have assumed... some area of 'femaleness' that ... makes possible female discourse" ("Constructing the Subject," 7). The relation of "femininity" to the "real" remains an unresolved and painful crux in feminist debate.

${ }^{31}$ Boose makes a similar observation: "Unlike feminism, new historicism is not, meanwhile, an activist politics of social change" ("Family in Shakespeare Studies," 740). 
events ought simply to be ignored or always reconstrued from the imagined perspective of women. ${ }^{32}$ Not only is this not possible, I doubt it is desirable. Many events in which the principal players have been men have had tremendous impact on women's lives; historical study cannot simply elide the role played by men or omit events traditionally associated with men, but must locate them with respect to women and others whom traditional scholarship has tended to overlook.

Each of these points requires fuller treatment than I can give it here. But I want to turn rapidly to Newton's first and most crucial point, in which she links the possibility of social change to "human agency." The book for which she reserves the highest praise-Mary Poovey's Uneven Developments: The Ideological Work of Gender in Mid-Victorian England-is the one that views change as effected by individual agents acting from choice and from conviction. The other two books are more limited, she argues, precisely because they reserve little place for individual agency, for old-fashioned activism. Thus she damns Gallagher's book: "Change ... emerges to a large degree from logical contradictions in representation itself and from a generalized need for new principles of cohesion.... Change does not emerge for the most part from human agents acting out of specific historical positions and with historically determined politics" (160). ${ }^{33}$ This view of change in history, for Newton, is "history as usual."

The limits of such a view are striking. To wish for the effectiveness of individual agency and to believe in it as the major force in history are two very different things, and Newton does not take up the intellectual and abstract argument about the basis of her belief. The debate about the role of the individual willed act in history is an ongoing and complex one, but none of that complexity emerges here. Instead, the critic who engages the innovative and open-minded view is characterized as backward-looking. It is Newton, it seems to me, who is more conservative in her epistemology, who is in fact practicing "history as usual."

These are not just fine points. Newton's is one of the most far-

${ }^{32}$ Neely makes a similar point even more forcefully: "The discursive practices of the cult-historicists would seem to produce, or to reproduce patriarchy. ... Once again, tragedy and history are the privileged genres. Once again, a focus on power, politics, and history, and especially, the monarch, turns attention away from marriage, sexuality, women, and the masterless" ("Constructing the Subject," 12). The critics Neely has in mind may in fact be guiltier of this than I find Gallagher to be.

${ }^{33}$ Porter, too, notes ruefully that in Greenblatt's work "power has been essentialized so as to absorb all agency" ("Are We Being Historical Yet?" 758). This point is central to Porter's critique of Greenblatt and the new historicism more generally; she gives it a balanced and sophisticated treatment. 
reaching feminist critiques of the new historicism. She questions, quite effectively, the feasibility of a feminist criticism that subscribes to the new historicist tenets. The critiques of Newton and others notwithstanding, feminist, new historicist criticism will continue to appear in the years to come. The critical positions are simply too persuasive, the thorny problems too intriguing, the framework for research and analysis too inviting for this new "school" —or critical mode, in both senses-to fail to gain even wider influence.

And yet the very uneasy labels of "school" and mode return us to an issue that we cannot comfortably ignore. When Newton attacks the new historicism primarily on the basis of its fraudulent novelty, she defends an ardently held political position, but she also goes for the jugular. It does call itself the new historicism, perhaps in contradistinction to the old historicism of German hermeneutics, but also, doubtless, out of a kind. of ground-staking impulse-or, to put it differently, a marketing sense. Never has an academic school been so effectively, if unintentionally, commodified. (The situation is rife with irony.) I take it as a symptom of this that The New Historicism, a timely volume indeed, seems to have represented in it nearly every big name in new historicist studies. ${ }^{34}$ The contributors themselves seem repeatedly embarrassed by the trendiness of their subject. It is telling that even in a volume that marks the emergence of this "school" into an easily accessible form, there is such disturbance, such guilt and hostility about the academic marketplace. The stakes are not negligible; we all know that the kind of fame a handful of scholars now enjoy brings with it salaries in the six figures, mobility, resources, and above all release time for reading and writing. And almost all of them-all but a handful of those who count themselves "new historicists" —are men.

Nevertheless, the new historicism remains the first major school of literary criticism in this country-aside from feminist criticism itselfthat not only has an acknowledged debt to feminism but also routinely embraces feminist positions and analytic practices. At least potentially,

\footnotetext{
${ }^{34}$ Here are Stephen Greenblatt, Catherine Gallagher, Louis Montrose, Joel Fineman, Jonathan Arac, and even Gayatri Spivak, Hayden White, and Stanley Fish-to name fewer than half the contributors. (Missing are the eminent women doing historicist work, such as Mary Poovey, Nancy Armstrong, Marjorie Levinson, Karen Newman, and Laura Brown, to name just a few.) What is more, I have never seen a volume so hastily edited. At least one of the essays is an untransformed talk, and one is a transcribed telephone conversation - not bad ideas in themselves, but further symptoms of the haste with which the volume was put together. There is no index. Much of the writing badly needs editorial revision, and there are more minor errors of punctuation and the like than I have ever seen in a published book. The reader has the impression altogether of tremendous haste: this volume approaches journalism in its sloppiness.
} 
the new historicism locates the analysis of gender construction at (or near) the very center of its analysis of culture, whether directly, through the study of masculinity and femininity, or more indirectly, through the study of concepts such as public versus private life, domestic culture, the function and theories of representation in varying social domains, and metaphors of value and exchange as they circulate among different groups.

What is the prognosis, finally, for the impact of the new historicism on a feminist comparative literature? Feminism does not yet have much of a history in comparative literature: it is still nearly a blank page. Comparative literature has so far proven a tough Bastille for feminists to storm. The comparatist Madwoman in the Attic has yet to be written. The comparatist journals have yet to publish much significant feminist work, and as late as 1990 the annual meeting of the American Comparative Literature Association had a real paucity of sessions on women writers and feminist topics. ${ }^{35}$

An emphasis on historicism, on concepts such as nationalism, the canon, and gender as historical, cultural constructs, may help open up and legitimize feminist areas of research in comparative literature. ${ }^{36}$ Despite the practical difficulties of doing comparatist historical research and the danger of slipping into facile generalizations, there is tremendous potential here for a new energy in comparative literature studies. One place to begin rewriting the disciplinary borders might well be with the questions: What are the relations between nations as constructs and cultural models of gender ${ }^{37}$ Are nations exclusively part of a malecentered political world? How do literary texts compare to other cultural documents in the ways they reinforce or undermine national boundaries? How do women and men place themselves with reference

\footnotetext{
${ }^{35} \mathrm{Of}$ forty-seven sessions, only four were organized around topics related to feminism or to women. See ACLA Newsletter 21. 2 (1990), conference program. Surveying issues of several comparative literature journals (Comparative Literature Studies, Arcadia, Comparative Literature, and the Canadian Review of Comparative Literature) from 1986 through 1990, I found only four essays (out of more than a hundred) that could be construed as feminist in method or subject-three of them in Comparative Literature Studies-and only two more on women writers.

${ }^{36}$ To some extent this process has begun, with the publication of works such as Margaret Ferguson, Maureen Quilligan, and Nancy Vickers, eds., Rewriting the Renaissance (Chicago: University of Chicago Press, 1986), and Constance Jordan, Renaissance Feminism: Literary Texts and Political Models (Ithaca: Cornell University Press, 1990).

${ }^{37}$ See, for example, Horst Rüdiger's disingenuous linking of the exotic with the feminine in the context of comparatist criticism: "In the background there is often another force at work.... It is the fascination with the Other, the foreign, the exotic, often in the form of the feminine," in "Grenzen und Aufgaben der Vergleichende Literaturwissenschaft," in Zur Theorie der Vergleichenden Literaturwissenschaft, ed. Horst Rüdiger (New York: de Gruyter, 1971), 13.
} 
to those processes, and what role do gender constructs play? This is only one set of questions on the table, but it may be one that comparatists in particular should address.

Comparatists might also make significant contributions to the history of print culture and its relation to gender constructs in an international context. What were the contours of feminine international literary cultures, in comparison and contradistinction to the masculine cultures which have been well researched? How are the hierarchies of aesthetic value that we have inherited related to the gendering of print cultures? What have been the historical relations between the gendering of commodity culture in market economies and the hierarchies of aesthetic value in the literary marketplaces? Two other specific arenas available for a feminist, historicist comparative literature come to mind: legal codes and wartime culture. What are the relations among laws such as those governing labor, copyright, and property on an international basis? How do literary representations of flight from domestic confinement treat borders between nations, legal codes, and cultures? Jane Marcus, in her essay in The New Historicism, has already pointed out some of the ways feminine wartime culture may differ from the masculine. How might such differences be charted in international terms?

These are just a few of the possibilities for a feminist, historicist comparative literature. It is probably not possible to reconceive comparative literature in collaboration with feminism without historicizing it-and it is the new historicism we must turn to here, for better or worse, not the history of Taine or of van Tieghem. 